\title{
Evaluation of the ecological function of amphitoxin in the reef-dwelling sponge Callyspongia (Euplacella) biru (Haplosclerida: Callyspongiidae) at southwest Sulawesi, Indonesia
}

\author{
Nicole J. de Voogd $1,2,{ }^{*}$, Joris J.H. Haftka ${ }^{1}$ and Bert W. Hoeksema ${ }^{2}$ \\ 1 Institute for Biodiversity and Ecosystem Dynamics, University of Amsterdam, P.O. Box 94766, 1090 GT Am- \\ sterdam, The Netherlands. ${ }^{2}$ National Museum of Natural History, 'Naturalis', P.O. Box 9517, 2300 RA Leiden, \\ The Netherlands. *E-mail:voogd@naturalis.nnm.nl
}

Keywords: Amphitoxin, Callyspongia (Euplacella) biru, Fungia fungites, Indonesia, Porifera, Spatial interaction

\begin{abstract}
The ecological function of the secondary metabolite amphitoxin produced by Callyspongia (Euplacella) biru is evaluated by a forced confrontation with the free-living scleractinian coral Fungia fungites at different exposure times. Our major goal was to determine whether such a forced confrontation with a spatial competitor would cause a significant change in the concentration of amphitoxin in the sponge tissue, indicating a regulatory mechanism of amphitoxin production. Firstly, the concentrations of amphitoxin of sponge fragments submitted to forced confrontation with a mushroom coral did not differ between the exposure times. Secondly, all sponge fragments, including the controls had a consistently lower amphitoxin concentration during the course of the experiment than the natural variation. Thirdly, the concentration of amphitoxin varied substantially between specimens implying that other ecological factors besides spatial competition regulate the production of bioactive compounds of C. biru.
\end{abstract}

\section{Contents}

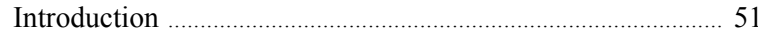

Material and methods .............................................................. 53

Experimental set-up and research site ................................ 53

Extraction and isolation ........................................................... 54

Thin Layer Chromatography .................................................. 54

Quantification of amphitoxin .............................................. 54

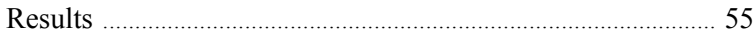

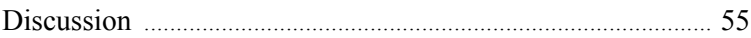

Acknowledgements ........................................................................ 57

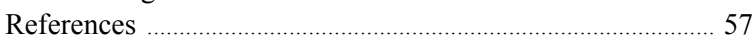

\section{Introduction}

In recent decades, marine invertebrates have attracted increasing interest as sources of bioactive metabolites from pharmaceutical companies and research institutions. Although more than 14,000 distinct natural products have been discovered from marine invertebrates, only few marine-derived compounds have passed pre- and clinical trials (Proksch et al., 2002; Mendola, 2003). In most cases the compound-producing marine organisms were haphazardly collected, without an understanding of the ecological function of these compounds. Recently, the question has arisen whether the function of these compounds could be deduced from field observations in order to collect only specimens of species that are expected to produce metabolites of pharmaceutical importance (Uriz et al., 1992; Proksch et al., 2002). Field observations can also be used to evaluate the biological aspects of the production of bioactive compounds for the feasibility of eventual mass production (Duckworth and Battershill, 2003). For instance, the absence of fouling organisms on soft-bodied invertebrates might indicate that the bioactive compounds in these invertebrates probably have potential anti-bacterial and/or fouling properties (Amade et al., 1987; Kelman et al., 2001). In addition to antifouling properties, the bioactive compounds may also act to deter predators, as shields for UV-protection, and as means for substrate acquisition (Aerts and van Soest, 1997; Assmann et al., 2000; de Voogd et al., 2004). Space is a highly restricted resource for sessile organisms when substrate availability is limited, such as in coral reefs (Dayton, 1971; Beccero et al., 2003). Extensive studies have assessed competitive mechanisms employed by scleractinian corals (Lang, 1973; Lang and Chornesky, 1990), corallimorpharians (Chadwick 1991; Chadwick and Adams, 1991), actiniarians (Bak and Borsboom, 1984), alcyonaceans (Benayahu and 
Loya, 1981), zoanthids (Suchanek and Green, 1982), bryozoans (Buss, 1979; Turner and Todd, 1994), and algae (Dai, 1991). Some of these mechanisms include: sweeper tentacles and mesenterial filaments (Bak et al., 1982; van Veghel et al., 1996), overgrowing and smothering (Cope 1982), and exudation of toxic substances (Rinkevich and Loya, 1983; Sammarco et al., 1983). Very few of these studies include sponges (Jackson and Buss, 1979; Buss, 1990). Sponges are a particularly rich source of secondary metabolites with anti-mitotic, cytotoxic, antibacterial, antifungal and/or antiviral properties (Faulkner, 1984; Munro et al., 1999). The ability of sponges to gain and hold space depends mainly on their competitive ability (Aerts and van Soest, 1997). Spatial competition can be visibly determined as overgrowth, necrosis, and bleaching of the interacting neighbour (Aerts, 2000). A few studies have suggested that waterborne biologically active metabolites may deter particular substrate competitors from growing in direct contact with sponges (Turon et al., 1996; Nishiyama and Bakus, 1999), but these chemicals have

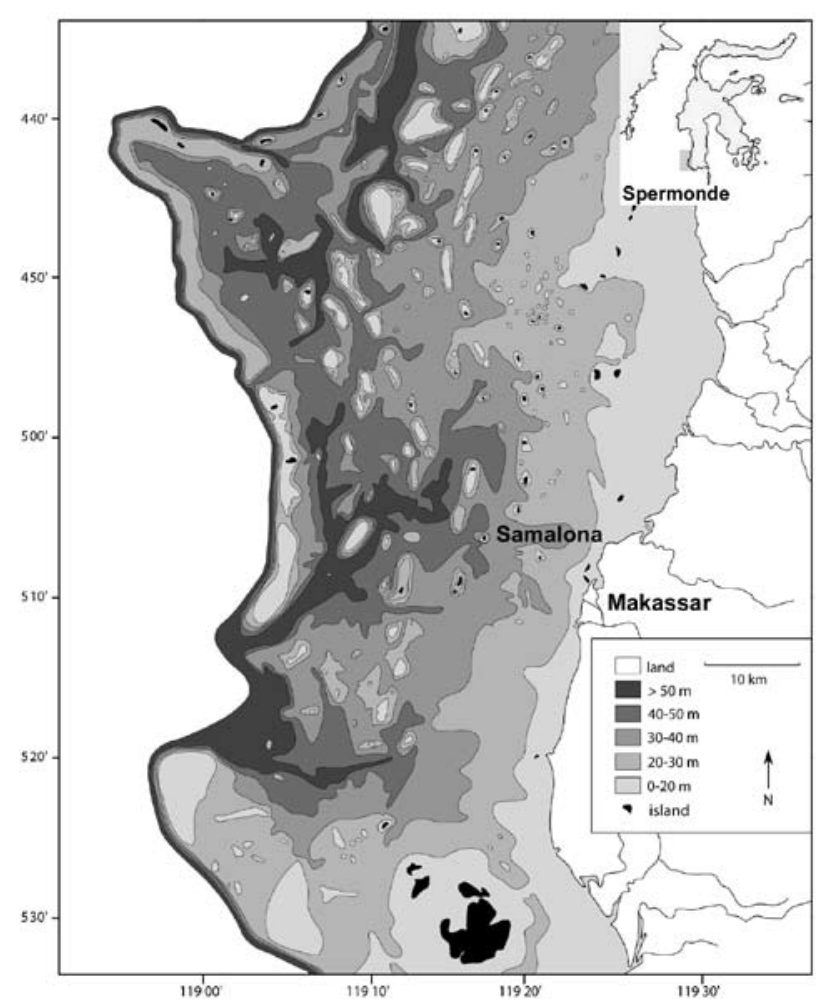

Fig. 1. Bathymetric map of the Spermonde Archipelago. Inset showing the location of the Spermonde Archipelago in relation to the island of Sulawesi. rarely been isolated or identified (Thompson et al., 1985; Thacker et al., 1998). Aerts and van Soest (1997) remarked that some sponges might be more aggressive towards corals in localities with high coral cover. Highly aggressive corals in the Caribbean are relatively minor reef components (Lang, 1973) while in the Indo-Pacific many of the most aggressive corals dominate (Sheppard, 1979; Dai, 1990). Nevertheless, in the Pacific, Rützler and Muzik (1993) reported spatial dominance and aggression in overgrowing corals of the sponge Terpios hoshinota in Japan and Guam.

Sponges of the genus Callyspongia (Callyspongiidae: Haplosclerida) are prominent and distinct components of Indonesian shallow-water coral reefs (van Soest 1989, 1990; de Voogd et al., 2004). Approximately 45 species have been described from Indonesia, and many more await description (van Soest, 1990; de Voogd and van Soest, 2002; de Voogd, 2004). Interestingly, a group of secondary metabolites, 3-alkylpiperidine alkaloids, have been recorded in all five families of the Haplosclerida, including Callyspongiidae, and are considered as a chemical marker for the order (Andersen et al., 1996; van Soest and Braekman, 1999). Pharmaceutical properties of these compounds include antifungal (Nicholas and Molinksi, 2000; Albrizio et al., 1995), antimicrobial (Schmitz et al., 1978; Kelman et al., 2001) and anticancer activities (Pettit et al., 1992). Albrizio et al. (1995) isolated the 3-alkylpiperidine alkaloid, amphitoxin from the Caribbean Amphimedon compressa Duchassaing and Michelotti, 1864 (Niphatidae) and recently this compound was isolated from the Indonesian sponges Amphimedon paraviridis Fromont, 1993 and several Callyspongia spp., including Callyspongia (Euplacella) biru de Voogd, 2004 (unpublished 'Symbiosponge' data).

Ecological studies on sponges producing this compound revealed deterrent properties towards several sponge predators and it was suggested that amphitoxin acts as an anti-feeding agent. (Albrizio et al., 1995; Pawlik et al., 1995; Burns et al., 2003). The selective toxicity of amphitoxin produced by the Red Sea sponge Amphimedon viridis Duchassaing and Michelotti, 1864 against different bacterial strains may keep this sponge free from microbial pathogenesis (Kelman et al., 2001). However, de Voogd et al. (2004) proposed that amphitoxin might play a role in competition for space with scleractinian corals. 


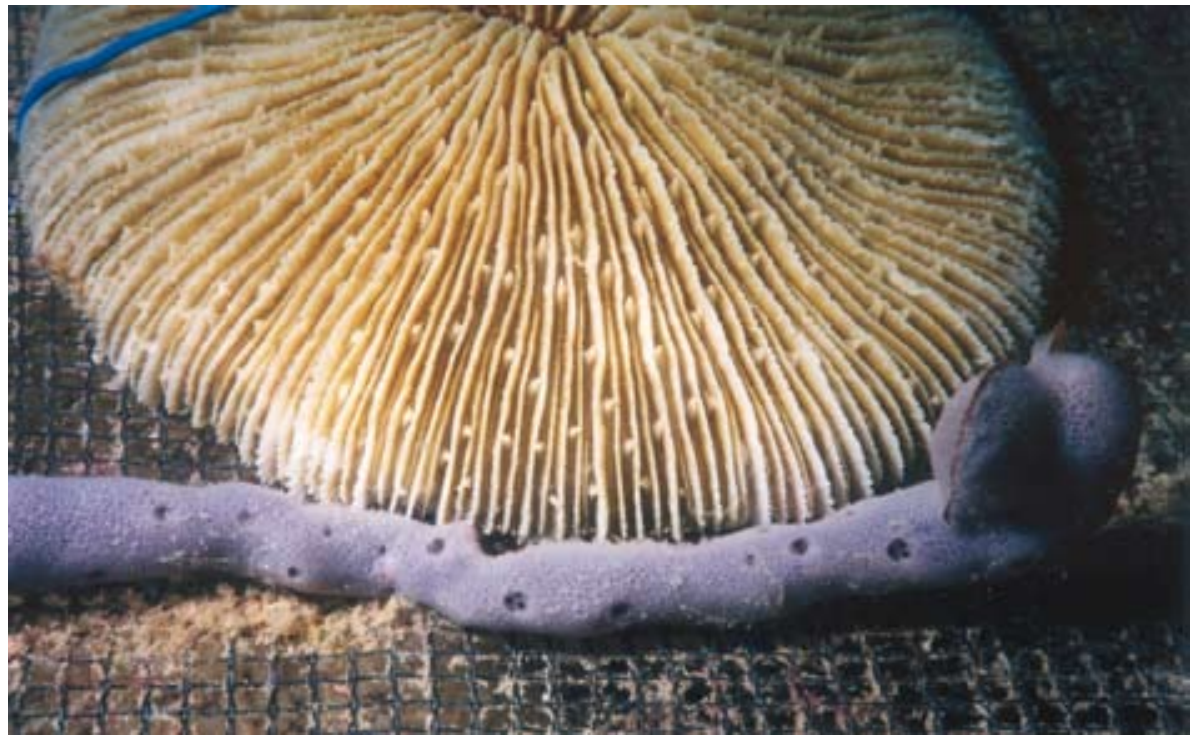

Fig. 2. A fragment of Callyspongia biru confronted with Fungia fungites at Samalona Island.

In the present study we evaluate the ecological function of amphitoxin produced by Callyspongia biru by a forced confrontation with a free-living scleractinian coral. Our major goal was to determine whether such a forced confrontation with a spatial competitor would cause a significant change in the concentration of amphitoxin in the sponge tissue, indicating a regulatory mechanism of amphitoxin production.

\section{Material and methods}

\section{Experimental set-up and research site}

This study took place at the northwest side of the fringing reef of Samalona island $\left(05^{\circ} 07.326^{\prime} \mathrm{S}\right.$ $\left.119^{\circ} 20.410^{\prime} \mathrm{E}\right)$ in the Spermonde Archipelago, $7 \mathrm{~km}$ off Makassar, SW Sulawesi, Indonesia from September to November 2002 (Fig. 1).

The sponge Callyspongia (Euplacella) biru de Voogd, 2004 (Callyspongiidae; Haplosclerida) was selected because its bioactivity and secondary metabolites are known. (Albrizio et al., 1995: unpublished 'Symbiosponge' data www.science.uva.nl/ZMA/ Invertebrates/Symbiosponge). Three types of experiments were performed, prior to the current experiment, to evaluate what environmental parameters might induce a change in bioactivity of the sponge crude extract. Sponge fragments were confronted with corals, injured repeatedly to simulate predator bites, and transplanted from deep to shallow water and vice versa to evaluate the impact of UV-radiation. A change in bioactivity was detected with the $\mathrm{Ar}$ temia-toxicity test (for a description of the Artemiatoxicity test see de Voogd, 2005). This test is an effective assay method to detect cytotoxic activity of secondary metabolites from terrestrial and marine organisms (Meyer et al., 1982; Richelle-Maurer et al., 2003), it has not been used to detect changes in bioactivity so far. Nevertheless, a change in bioactivity (mortality of Artemia nauplii $\geq 50 \%$ exposed to the crude extract of $C$. biru varying between $1 \mathrm{mg} / \mathrm{L}$ and $10 \mathrm{mg} / \mathrm{L}$ ) was revealed in the experimental confrontation of the sponge with a coral (Bavinck, 2001; Becking, 2002); thus this experimental set-up was chosen for quantification of amphitoxin. Twenty branch fragments of approximately $12 \mathrm{~cm}$ length of living sponge were collected at a depth of $12 \mathrm{~m}$ and attached to a frame with electric cable wire with a protective plastic sheath at the same depth. Frames were made of PVC tubes of a rectangular form (70 $\times 100 \mathrm{~cm})$ on which nylon fishing net had been tightened. The free-living coral Fungia fungites Linnaeus, 1758 (Scleractinia: Fungiidae; see Hoeksema, 1989 ) is known to be an aggressive competitor for space (Hildemann et al. 1975; Thomason and Brown, 1986). After the sponges were allowed to acclimatize 


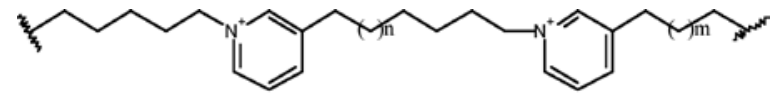

A

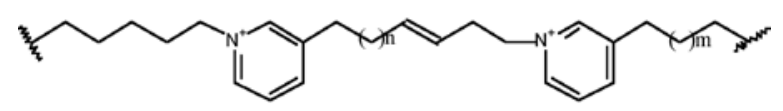

$\underline{\mathbf{B}}$

Fig. 3. Chemical structure of isolated amphitoxin A and amphitoxin B.

for a period of four weeks, 16 individuals of the coral were collected and placed on the frames at a distance of $0.5-1 \mathrm{~cm}$ to an equal number of sponge fragments. In a similar manner to the sponges, the corals were tied to the frame with cable wire to keep the neighbouring coral and sponge in place (Fig. 2). Four sponge fragments were used as controls, and these were not confronted with the coral. Two of these fragments were collected at the beginning of the experiment and the remaining two fragments were left on the frame without coral confrontation, until their collection at the end of the experiment. Of the 16 sponge fragments confronted with the corals, two fragments were collected at eight different time intervals; $\mathrm{T} 1=1 / 2$ hour, $\mathrm{T} 2=1$ hour, $\mathrm{T} 3=4$ hours, $\mathrm{T} 4=24$ hours, and T5 $=72$ hours, T $6=8$ days, T7 $=19$ days and $\mathrm{T} 8=28$ days. For the natural variation, three sponge fragments of approximately 12 $\mathrm{cm}$ in length were collected from different depths at different locations at the reef surrounding the island of Samalona.

\section{Extraction and isolation}

The sponge fragments were measured (length in $\mathrm{cm}$; growth in thickness was not observed) and extracted in $\pm 50 \mathrm{ml}$ pure methanol for 24 hours at room temperature immediately upon collection. Preliminary investigation with this sponge showed that the methanolic extract was found to be active and contained the 3-alkylpiperidine alkaloids. We therefore

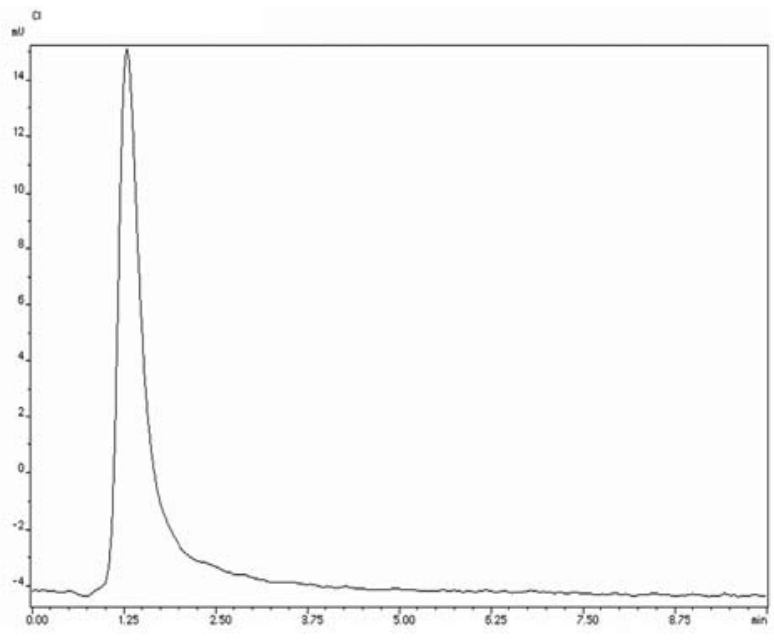

Fig. 4. Callyspongia biru. HPLC chromatogram of MeOH extract. The peak corresponds to Amphitoxin A + B.

only used pure methanol for extraction. The sponges were cut into smaller pieces and were washed twice in succession with the solvent to ensure an exhaustive extraction. All the filtrates were combined, and placed in a cooled evaporator. The crude extract was collected and weighed after approximately 24 hours of evaporation and stored at $7^{\circ} \mathrm{C}$. Detection of the 3alkylpiperidine alkaloids was determined using Thin Layer Chromatography.

\section{Thin Layer Chromatography}

Although 3-alkylpiperidine alkaloids have previously been isolated from $C$. biru, the presence of these alkaloids was verified for several sponge fragments prior to HPLC-quantification. A capillary tube was held in the methanolic sponge extract and carefully spotted five times onto $0.25 \mathrm{~mm} \mathrm{Si-gel} \mathrm{coated}$ sheets $(5 \times 2 \mathrm{~cm})$. The plates were eluted with a solvent mixture containing water / acetonitrile (7:3) $+0.1 \%$ trifluoroacetic acid. After the completion of the chromatography, the dried plates were sprayed with a solution of Dragendorff reagent. 3-alkylpiperidine alkaloids can be detected as one of the major compounds present in the extract and appears as a bright orange spot.

\section{Quantification of amphitoxin}

Analysis of amphitoxin was performed by high-performance liquid chromatography (HPLC) with a 

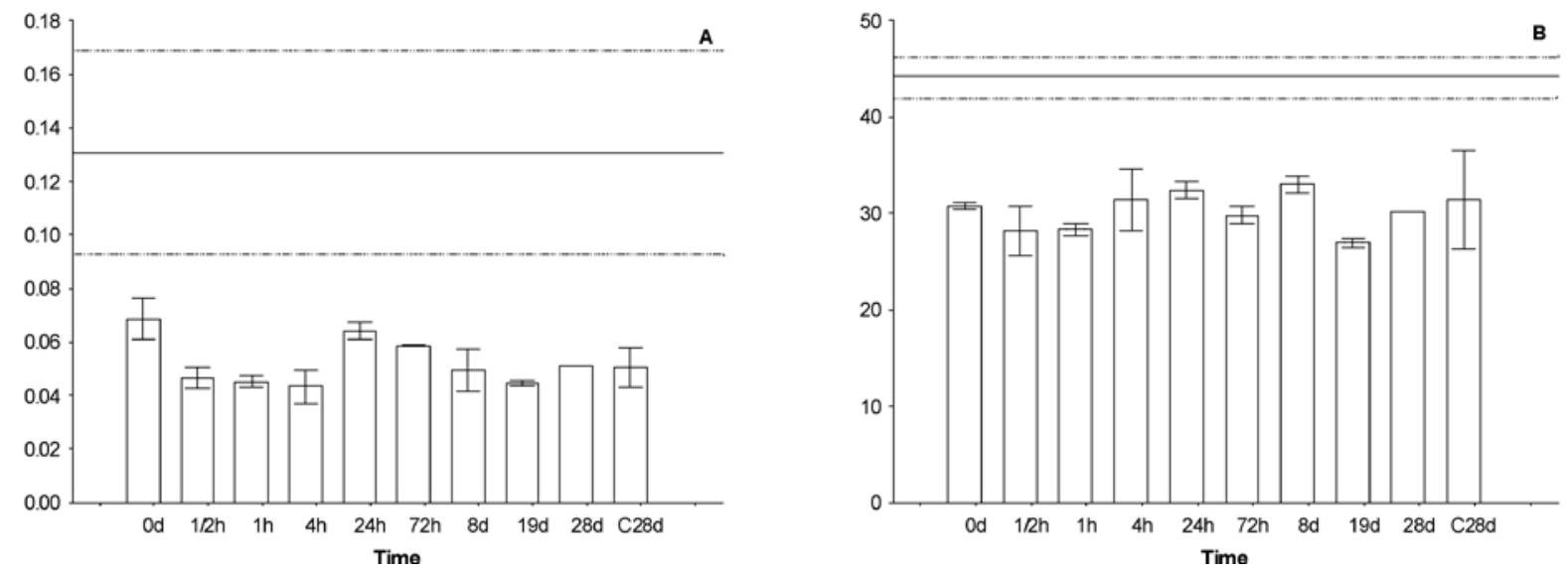

Fig. 5.(A) Mean \% concentration of amphitoxin / dry weight of sponge mass (bars and $\pm 1 \mathrm{SE}$ ). (B) Mean $\%$ concentration of crude extract /dry weight of sponge mass over time (in $\mathrm{h}=$ hours and $\mathrm{d}=$ days) and in control sponges at the start and the end of the experimental period (0d and C28d). Mean natural concentrations are indicated by a line \pm (dotted line 1SE).

Waters 600E system controller equipped with a Waters 717 plus autosampler and a Waters 848 Tunable Absorbance Detector. Crude extracts from the sponge fragments were dissolved in a mixture (70:30) of water and acetonitrile $+0.1 \%$ trifluoroacetic acid and $10 \mu 1$ was injected by auto-sampling into an HPLCsystem. The column used was a Lichrospher RP18 (125 by $2.0 \mathrm{~mm}$ with a $3 \mu \mathrm{m}$ pore size) and the mobile phase consisted of acetonitrile (70\%) and nanopure water $(30 \%)$ with trifluoroacetic acid $(0.1 \%)$ at a flow rate of $1 \mathrm{ml} / \mathrm{min}$. Amphitoxin was detected at its UV-maximum of $266 \mathrm{~nm}$. The quantitative analysis was based on peak area calibration using earlier purified amphitoxin (Fig. 3). We compared our data with spectral data reported in the literature (Albrizio et al., 1995). To calculate the percent yield of amphitoxin, we calculated the mass amphitoxin divided by the mass of dried sponge, multiplied by 100 . The percentage yield of the total crude extract was calculated as the mass of the extract divided by the mass of dried sponge, multiplied by 100 .

\section{Results}

The concentrations of amphitoxin / dry weight of sponge fragments submitted to forced confrontation with a coral did not differ between the time intervals. All sponge fragments, including the controls ( $0 \mathrm{~d}$ and C28d), attached to the PVC-frame had a consist- ently lower mean amphitoxin concentration per dry weight than the natural variation (Fig. 5A). The percentage amphitoxin varied from $0.04-0.07 \%$ of the dry weight of the fragments, whereas the percentage for the natural variation varied from $0.06-0.20 \%$ of the dry weight. Also, the mean percentage crude extracts / dry weights were consistently lower than that of the natural variation. All sponge fragments, including the natural variation, exhibited a large interindividual variability. The mean crude extract per dry weight of the natural variation varied between $42-48 \%$, whereas this was only $26-37 \%$ for the fragments of the experimental set-up (Fig. 5B). The sponge fragments were measured after transplantation and after collection, and all sponge fragments showed at least $10 \%$ growth in a period of at least four weeks. White (bleached) spots in the area adjacent to the sponges were observed in some of the individuals of Fungia fungites after several days.

\section{Discussion}

In the present study we evaluated the ecological function of the major secondary metabolite, amphitoxin, produced by Callyspongia (Euplacella) biru by confronting this species with the space competitor Fungia fungites. Importantly, all sponge specimens analysed with HPLC in this study were found to contain amphitoxin. Amphitoxin is known to be 
mainly responsible for the bioactivity of the crude extract of the Indonesian sponge C. biru (Dubut, 2000). The mean percentage amphitoxin concentration per dry weight was consistently lower for all sponge fragments, including the control fragments, during the course of the experiment than the amphitoxin concentration of the natural variation. In a similar experiment to ours, the Caribbean sponge Agelas conifera Schmidt, 1870 was experimentally confronted with the scleractinian coral Madracis sp., and no significant change in bioactive compound concentration was observed. In the same study, inflicted sponge damage induced a fourfold rise in concentration, and yielded detectable amounts of the Agelas alkaloids in the surrounding seawater, suggesting allelopathic activity (Richelle-Maurer et al., 2003). Although a detection analysis of the chemicals in the surrounding seawater was not performed in the present study, the lower concentrations of amphitoxin in the experimental sponge fragments might imply allelopathic activity. Several studies (Porter and Targett, 1988; Nishiyma and Bakus, 1999; Engel and Pawlik, 2000) suggested that water borne allelochemicals might deter substrate competitors from growing in direct contact with sponges. Sullivan et al. (1983) isolated secondary metabolites excreted within mucus from an excavating sponge, which inhibits coral growth. Turon et al. (1996) suggested that the sponge Crambe crambe Schmidt, 1862 releases waterborne chemicals and may cause tissue necrosis to adjacent organisms at small scales.

Certain tolerant coral species, however, may grow adjacent to sponges, whereas others are rarely or never found in close proximity. Nishiyama and Bakus (1999) demonstrated that three sponges released allelochemicals into the surrounding seawater, and were toxic to several scleractinian coral species. Although they did not quantify the secondary metabolites in the sponge tissue, these results suggest the release of compounds into the seawater. It is possible that the release of allelochemicals into the surrounding seawater of the confronted sponges in the present study might trigger non-confronted proximate individuals to release their toxins as well, and might explain the lower concentrations of amphitoxin in the control sponges. Besides, it is known that certain green algae rapidly transform stored non-active compounds into very reactive toxins upon mechanical wounding (Paul and Van Alstyne, 1992; Jung and
Pohnert, 2001). However, it is not known in sponges, whether such enzymatic transformations take place upon wounding or during other stress events. Notwithstanding, the sponges exhibited a large interindividual variation, indicating a regulatory mechanism for the production of amphitoxin. Thacker et al. (1998) found no evidence that the production of secondary metabolites was induced by the presence of a spatial competitor, rather they suggested that the constant threat of predators may maintain high concentrations of the compound. They also observed a large variation in the production of secondary metabolites, which according to them might be due to differences in nutrient availability or genetic differences. Thus an increase or decline in the production of secondary metabolites may not be so clearly attributed to the presence of spatial competitors or predators. On the other hand, the ecological role and strength of pure metabolites, in this case amphitoxin, may be quite different from the total crude extract. From unpublished records, it was hypothesized that amphitoxin was responsible for the general toxicity of this particular species (Artemia-toxicity-test). Besides, the mean percentage crude extract per dry weight was consistently lower from the manipulated sponge fragments than those of the natural variation. However, it has been suggested that different metabolites present in a species may interact and produce different bioactivities when tested together or separately. Although no other major metabolites have been isolated from this sponge species, other chemical products, even salts, may have a synergetic effect on its bioactivity (Marti et al., 2003).

The optimal defense theory assumes that the production of defensive secondary metabolites is costly and consequently would repress growth and reproduction (Schupp et al., 1999). In the present study, all sponge fragments did grow at least $10 \%$ during the experimental period, and upon collection, larvae were observed in the tissue of several sponge fragments. Richelle-Maurer et al. (2003) suggested that there is always a minimal production of bioactive compounds possibly at the boundary of efficiency. Thus, it is probable, that wounded individuals invest their limited available energy in healing and growth rather than in the production of secondary metabolites. However, some of the individuals of $F$. fungites were observed with white spots during the course of the experiment confronted with $C$. biru suggesting 
exudation of secondary metabolites and competitive dominance of the sponge, although other enviromental stressors may have induced bleaching of the corals (cf. Hoeksema, 1991). Scleractinian corals are in general sedentary animals, however most mushroom corals (Fungiidae) have a free-living phase in their life cycle (Hoeksema, 1989). Mobility may help mushroom corals to disperse and reach favourable habitats, to prevent burial in soft sediments or to function in avoiding competition for space (Hoeksema, 1988, 1993; Chadwick, 1988; Chadwick-Furman and Loya, 1992). Fungiid corals, however, have been shown to competitively dominate non-fungiid scleractinians during interactions in physical contact experiments (Chadwick-Forman and Loya, 1992). The thick mucus secreted by most unattached mushroom corals may have a protective function in aggressive reactions during accidental contact with other sedentary organisms (Hildemann et al., 1975; Chadwick, 1988). Competitive interactions with other sessile invertebrates though, are only known with octocorals, where the interacting organisms appear not to harm each other (Chadwick-Forman and Loya, 1992). Also, observations of natural interactions of $C$. biru with scleractinian corals demonstrated necrosis in more than $90 \%$ of overgrowth interactions (de Voogd et al., 2004). In conclusion, although a forced confrontation of the sponge $C$. biru with the scleractinian $F$. fungites showed a consistently lower amphitoxin concentration compared to the natural variation, this may not be so straightforward be attributed to a competitive regulatory mechanism induced by the spatial competitor. Rather, the concentration of amphitoxin varies substantially between specimens implying that other ecological factors besides spatial competition interact to regulate the production of bioactive compounds of $C$. biru. More importantly, in scope of eventual mass production, manipulated sponges might produce consistently lower concentrations of the target bioactive compound than sponges in their natural environment.

\section{Acknowledgements}

This research was funded by the Netherlands Foundation for the Advancement of Tropical research (WOTRO grant W84-474). The Indonesian Foundation for Research (LIPI) provided the research permits. The first author is very grateful for the help Prof
J.C. Braekman provided with various aspects on the chemistry of Callyspongia biru and for letting me work in his laboratory at ULB, Belgium. Vera Bavinck and Lisa Becking are thanked for their help with the preliminary experiments. Rob W.M. van Soest, Daniel F. R. Cleary and two anonymous reviewers are thanked for comments on earlier versions of the manuscript.

\section{References}

Aerts LAM. 2000. Dynamics behind standoff interactions in three reef sponges species and the coral Monastrea cavernosa. PSZN: Mar. Ecol. 21 (3-4): 191-204.

Aerts LAM, Soest RWM van. 1997. Quantification of spongecoral interactions in a physically stressed reef community in NE Colombia. Mar. Ecol. Prog. Ser. 148: 125-134.

Albrizio S, Ciminiello P, Fattorusso E, Magno S, Pawlik JR. 1995. Amphitoxin, a high-molecular-weight antifeedant pyridium salt from the Caribbean sponge Amphimedon compressa. J. Nat. Prod. 58 (5); 647-652.

Amade O, Charroin C, Baby C, Vacelet J. 1987. Antimicrobial activities of marine sponges from the Mediterranean Sea. Mar. Biol. 94: 271-275.

Andersen RJ, van Soest RWM, Kong F. 1996. 3-Alkylpiperidine alkaloids isolated from marine sponges in the order Haplosclerida. Pp. 301-356. In Pelletier, S.W. (ed.) Alkaloids: Chemical and biological perspectives. Vol. 10. (Pergamon: Oxford).

Assmann M, Lichte E, Pawlik JR, Köck M. 2000. Chemical defenses of the Caribbean sponges Agelas wiedenmayeri and Agelas conifera. Mar. Ecol. Prog. Ser. 207: 255-262.

Bak RPM, Borsboom JLA. 1984. Allelopathic interaction between a reef coelenterate and benthic algae, Oecologia (Berl) 63: 194-198.

Bak RPM, Termaat RM, Dekker R. 1982. Complexity of coral interactions: influence of time, location of interaction and epifauna. Mar. Biol. 69: 215-222.

Bavinck V. 2001 Environmental factors correlated with bioactivity of the sponge Callyspongia sp. Student report, University of Amsterdam, the Netherlands.

Beccero MA, Thacker RW, Turon X, Uriz MJ, Paul VJ. 2003. Biogeography of sponge chemical ecology: comparisons of tropical and temperate defenses. Oecologia 135: 91-101.

Becking LE. 2002 Sponge interactions with spatial competitors. Student report, University of Amsterdam, the Netherlands.

Benayahu Y, Loya Y. 1981. Compettion for space among coralreef sessile organisms at Eilat, Red Sea. Bull. Mar Sci 31: 514-522.

Blunt JW, Munro MHG. 2003. MarinLit. A database of the literature on marine natural products for use on a Macintosh computer prepared and maintained by the Marine Chemistry Group (Department of Chemistry, University of Canterbury: Canterbury, New Zealand).

Buss LW. 1979. Bryozoan overgrowth interactions - the interdependence of competition for space and growth. Nature 281: 475-477.

Buss LW. 1990. Competition within and between encrusting clonal invertebrates. Trends Ecol. Evol. 5: 352-356. 
Chadwick NE. 1988. Competition and locomotion in a free-living fungiid coral. J. Exp. Mar. Biol. Ecol. 123: 189-200.

Chadwick NE. 1991. Spatial distribution and the effects of competition on some temperate Scleractinia and Corallimorpharia. Mar. Ecol. Prog. Ser. 70: 39-48.

Chadwick NE, Adams C. 1991. Locomotion, asexual reproduction, and killing of corals by the corallimorpharian Corynactis californica. Hydrobiologia 216/217: 263-269.

Chadwick-Furman NE, Loya Y. 1992. Migration, habitat use, and competition among mobile corals (Scleractinia: Fungiidae) in the Gulf of Eilat, Red Sea. Mar. Biol. 114: 617-623.

Cope M. 1982. Interspecific coral interactions in Hong Kong. Proc $4^{\text {th }}$ Int. Coral Reef Symp., Manila, 1981, 2: 357-362.

Dai CF. 1990. Interspecific competition in Taiwanese corals with special reference to interactions between alcyonaceans and scleractinians. Mar. Ecol. Prog. Ser. 60: 291-297.

Dai CF. 1991. Distribution and adaptive strategies of alcyonacean corals in Nanwan Bay, Taiwan. Hydrobiologia 216/217: 241246.

Dayton PK. 1971. Competition, disturbance and community organization: the provision and subsequent utilization of space in a rocky intertidal community. Mar. Ecol. Prog. Ser. 60: 291-297.

Dubut D. 2000. Isolément et détermination de structure de toxins d'éponges du genre Callyspongia. Student Report, Université Libre de Bruxelles, Belgium.

Duckworth A, Battershill C. 2003. Sponge aquaculture for the production of biologically active metabolites: the influence of farming protocols and environment. Aquaculture 221: 311-329.

Engel S, Pawlik JR. 2000. Allelopathic activities of sponge extracts. Mar. Ecol. Prog. Ser. 207: 273-281.

Faulkner DJ. 1984. Marine natural products: metabolites of marine invertebrates. Nat. Prod. Rep. 1: 551-598.

Hildemann WH, Linthicum DS, Vann DC. 1975. Transplantation and imunoincompatibility reactions among reef-building corals. Immunogenetics 2: 269-284.

Hoeksema BW. 1988. Mobility of free-living fungiid corals (Scleractinia), a dispersion mechanism and survival strategy in dynamic reef habitats. Proc $6^{\text {th }}$ Int. Coral Reef Symp 2: 715-720.

Hoeksema BW. 1989. Taxonomy, phylogeny and biogeography of mushroom corals (Scleractinia: Fungiidae). Zool. Verh. Leiden 254: 1-295.

Hoeksema BW. 1991. Control of bleaching in mushroom coral populations (Scleractinia: Fungiidae) in the Java Sea: stress tolerance and interference by life history strategy. Mar. Ecol. Prog. Ser. 74: 225-237.

Hoeksema BW. 1993. Phenotypic corallum variability in recent mobile reef corals. Cour. Forschinst. Senckenb. 164: 263272.

Jackson JBC, Buss L. 1975. Allelopathy and spatial competition among coral reef invertebrates. Proc. Nat. Acad. Sci. U.S.A. 72: 5160-5163.

Jung V, Pohnert G. 2001. Rapid wound-activated transformation of the green algal defensive metabolite caulerpenyne. Tetrahedron 57: 7169-1712.

Kelman D, Kashman Y, Rosenberg E, Ilan M, Ifrach I, Loya Y. 2001. Antimicrobial activity of the reef sponge Amphime- don viridis from the Red Sea: evidence for selective toxicity. Aquat. Microb. Ecol. 24: 9-16.

Lang JC. 1973. Interspecific aggression by scleractinian corals. 2. Why the race is not only to the swift. Bull. Mar. Sci. 23: 260-279.

Lang JC, Chornesky EA. 1990. Competition between scleractinian reef corals - a review of mechanisms and effects. In Dubinsky Z, ed: Ecosystems of the world 25. Coral Reefs. Elsevier, Amsterdam, 209-252.

Marti R, Fontana A, Uriz MJ, Cimino G. 2003. Quantitative assessment of natural toxicity in sponges: toxicity bioassay versus compound quantification. J. Chem. Ecol. 29 (6): 1307 1318.

Mendola D. 2003. Aquaculture of three phyla of marine invertebrates to yield bioactive metabolites: process developments and economics. Biomol. Engineer. 20: 441-458.

Meyer BN, Ferrigni NR, Putnam JE, Jacobsen LB, Nichols DE, McLaughlin JL. 1982. Brine shrimp - A convenient general bioassay for active plant constituents. Planta Medica 45: 31-34.

Munro MHG, Blunt JW, Dumdei EJ, Hickford SJH, Lill RE, Li S, Battershill CN, Duckworth AR. 1999. The discovery and development of marine compounds with pharmaceutical potential. J. Biotechnol. 70: 15-25.

Nicholas GM, Molinski TF. 2000. Structures of cribochalines $\mathrm{A}$ and $\mathrm{B}$, branched-chain methoxylaminoalkyl pyrdines from the Micronesian sponge, Cribochalina sp., absolute configurations and enantiomeric purity of related O-methyl oximes. Tetrahedron 56 (19): 2921-2927.

Nishiyama GK, Bakus GJ. 1999. Release of allelochemicals by three tropical sponges (Demospongiae) and their toxic effects on coral substrate competitors. Mem. Qld. Mus. 44: 411-417.

Paul VJ, Van Alstyne KL. 1992. Activation of chemical defenses in the tropical green algae Halimeda spp. J. Exp. Mar. Biol. Ecol. 160: 191-203.

Pawlik JR, Chanas B, Toonen RJ, Fenical W. 1995. Defenses of Caribbean sponges against predatory reef fish. I. Chemical deterrence. Mar. Ecol. Prog. Ser. 127: 183-194.

Pettit GR, Collins JC, Herald DL, Doubek DL, Boyd MR, Schmidt JM, Hooper JNA, Tackett LP. 1992. Isolation and structure of cribrostatin-1 and cribrostatin-2 from the blue marine sponge Cribrochalina sp. Can. J. Chem. 70: 1170-1175.

Porter JW, Targett NM. 1988. Allelochemical interactions between sponges and corals. Biol. Bull.175: 230-239.

Proksch P, Edrada RA, Ebel R. 2002. Drugs from the seas - current status and microbiological implications. Appl. Microbiol. Biotechnol. 59: 125-134.

Richelle-Maurer E, De Kluijver MJ, Feio S, Gaudêncio S, Gaspar H, Gomez R, Tavares R, Van de Vyver G, Soest RWM van. 2003. Localization and ecological significance of oroidin and sceptrin in the Caribbean sponge Agelas Conifera. Biochem. Syst. Ecol. 31: 1073-1091.

Rinkevich B, Loya Y. 1983. Intraspecific competitive networks in the Red Sea coral Stylophora pistillata. Coral Reefs 1: 161-172.

Rützler K, Muzik K. 1993. Terpios hoshinota, a new cyanobacteriosponge threatening Pacific Reefs. Sci. Mar. 57: 395-403. 
Sammarco PW, Coll JC, La Barre SC, Willis B. 1983. Competitive strategies of soft corals (Coelenterata: Octocorallia): Allelopathic effects on selected scleractinian corals. Coral Reefs 1: 173-178.

Schupp P, Eder C, Paul V, Proksch P. 1999. Distribution of secondary metabolites in the sponge Oceanapia sp. and its ecological implications. Mar. Biol. 135: 573-580.

Schmitz FJ, Hollenbeak KH, Campbell DC. 1978. Marine natural products: halitoxin, toxic complex of several marine sponges of the genus Haliclona. J. Org. Chem. 43: 39163922.

Sheppard CRC. 1979. Interspecific aggression between reef corals with reference to their distribution. Mar. Ecol. Prog. Ser. 1: 237-247.

Soest RWM van. 1989. The Indonesian sponge fauna: A status report. Neth. J. Sea Res. 23: 223-230.

Soest RWM van. 1990. Shallow-water reef sponges of Eastern Indonesia. In: Rützler K, ed. New perspectives in sponge biology. Smithsonian Inst. Press, Washington, USA, 302308.

Soest, RWM van, Braekman JC. 1999. Chemosystematics of Porifera: A Review. Mem. Qld. Mus. 44: 569-589.

Suchanek TH, Green DJ. 1982. Interspecific competition between Palythoa caribaeorum and other sessile invetebrates on St. Croix reefs, U.S. Virgin Islands. Proc. $4^{\text {th }}$ Int. Coral Reef Symp Manila,1981, 2: 679-684.

Thacker RW, Beccero MA, Lumbang WA, Paul VJ. 1998. Allelopathetic interactions between sponges on tropical reefs. Ecology 79: 1740-1750.

Thomason JC, Brown BE. 1986. The cnidom: an index of aggressive proficiency in scleractinian corals. Coral Reefs 5: 93-101.
Thompson JE, Walker RP, Faulkner DJ. 1985. Screening and bioassys for biologically-active substances from marine sponges species from San Diego, California, USA. Mar. Biol. 88: $11-21$.

Turner SJ, Todd CD. 1994. Competition for space in encrusting bryzoan assemblages: the influence of encounter angle, site and year. J. Mar. Biol. Ass. 74: 603-622.

Turon X, Beccero MA, Uriz MJ, Llopis J. 1996. Small-scale associations measures in epibentic communities as a clue for allelochemical interactions. Oecologia 108: 351-360.

Uriz MJ, Martin D, Rosell D. 1992. Relationships of biological and taxonomic characteristics to chemically mediated bioactivity in Mediterranean littoral sponges. Mar. Biol. 113: 287-297.

van Veghel MLJ, Cleary DFR, Bak RPM. 1996. Interspecific interactions and competitive ability of the polymorphic reefbuilding coral Montastrea annularis. Bull. Mar. Sci. 58 (3): 792-803.

de Voogd NJ. 2004. Callyspongia (Euplacella) biru spec.nov. (Porifera: Demospongiae: Haplosclerida) from Indonesia. Zool. Med. Leiden 78: 477-483.

de Voogd NJ. 2005. Indonesian sponges: Biodiversity and mariculture potential. PhD-thesis. University of Amsterdam.

de Voogd NJ, Becking LE, Hoeksema BW, Noor A, van Soest RWM. 2004. Sponge interactions with spatial competitors in the Spermonde Archipelago. Bull. Mus. Ist. Biol. Univ. Genova 68: $253-261$.

de Voogd NJ, van Soest RWM. 2002. Indonesian sponges of the genus Petrosia Vosmaer (Demospongiae: Haplosclerida). Zool. Med. Leiden 76: 193-209.

Received: 18 November 2004

Accepted: 6 June 2005 
